\title{
EFFECT OF CONAGENIN IN TUMOR BEARING MICE ANTITUMOR ACTIVITY, GENERATION OF EFFECTOR CELLS AND CYTOKINE PRODUCTION
}

\author{
Masaji Kawatsu, Takashi Yamashita, Michiyo Osono, Tohru Masuda, \\ MASAAKI ISHIZUKA* and TOMIO TAKEUCHI \\ Institute for Chemotherapy, M.C.R.F., \\ 18-24 Aza Motono, Miyamoto, Numazu-shi, \\ Shizuoka 410-03, Japan
}

(Received for publication May 28, 1993)

\begin{abstract}
Antitumor effects and function of $\mathrm{T}$ cells in tumor bearing mice given conagenin (CNG), a low molecular immunomodulator, were investigated. The administration of $\mathrm{CNG}$, once a week for 4 weeks, was the most effective schedule in inhibiting growth of IMC carcinoma, a syngeneic tumor. In this regimen, cytotoxic T lymphocytes and natural killer activities in spleens of CNG treated mice were maintained at higher levels than those of non-treated mice. Lymphokine production by splenic $\mathrm{T}$ cells was also enhanced in cultures, whereas monokine production by macrophages, which was increased in accordance with tumor growth, was reduced by CNG administration.

The autitumor effect of CNG was not observed in mice given anti-asialo GM1 serum and in athymic mice.

Results shown in this report suggest that CNG exerts its antitumor effects through activation of $T$ cells and enhancement of generation of antitumor effector cells.
\end{abstract}

It is known that immunomodulators such as ubenimex ${ }^{1)}$, forphenicinol ${ }^{2)}$ and $\mathrm{MDP}^{3)}$ stimulate $\mathrm{T}$ cells through activation of macrophages. They have shown antitumor effects on murine transplantable tumor models ${ }^{4 \sim 7)}$. Polysaccharides such as lentinan ${ }^{8 \sim 10)}$, sizofilan ${ }^{11,12)}$ and PS-K ${ }^{13)}$ activate macrophages and $\mathrm{T}$ cells. However, it can be considered that the activation of macrophages induces non-specific augmentation in the host immune system, and high molecular substances such as $\beta$-glucan and LPS can show side-effects by their inflammatory activities.

Thus, we have sought immunomodulators which act on activated $T$ cells exclusively and found conagenin $(\mathrm{CNG})$, a low molecular immunomodulator, in cultured broth of Streptomyces roseosporus ${ }^{14}$. In this paper, we report antitumor effects of $\mathrm{CNG}$ and modulation of $\mathrm{T}$ cell functions in tumor bearing mice given $\mathrm{CNG}$.

\section{Materials and Methods}

Mice

$\overline{\mathrm{CDF}}_{1}$ mice, 6 weeks old, were purchased from Charles River Japan Inc. (Kanagawa, Japan), and were maintained under specific pathogen-free conditions at $23 \pm 1^{\circ} \mathrm{C}$ and $55 \pm 5 \%$ humidity. BALB/c $\mathrm{nu} / \mathrm{nu}(-)$ mice, 6 weeks old, purchased from Japan SLC Inc. (Shizuoka, Japan), were kept in a clean rack with the above conditions. These mice were employed for experiments at $9 \sim 11$ weeks of age.

Conagenin

Conagenin $(\mathrm{CNG})$ was prepared according to the procedures reported ${ }^{14)}$ by KANEKA Co. Ltd. (Osaka, Japan). For experiments, CNG was dissolved in sterilized saline. 
Antitumor Activity

IMC carcinoma cells were maintained in $\mathrm{CDF}_{1}$ mice by weekly intraperitoneal transfer. Cells $\left(1 \times 10^{6}\right.$ cells) were inoculated $s c$ to the inguinal region of $\mathrm{CDF}_{1}$ mice. $\mathrm{CNG}$ was administered ip on various schedules starting at day 1 after tumor inoculation.

Antitumor activity was determined by measuring tumor volume $\left(\mathrm{mm}^{3}\right)$ at weekly intervals and by weighing at day 35 after the inoculation. The tumor volume was determined by the following formula: Tumor valume $\left(\mathrm{mm}^{3}\right)=$ length $(\mathrm{mm}) \times$ width $(\mathrm{mm})^{2} \times 0.5$. The percentage of inhibition of tumor weight was calculated as follows: Inhibition $(\%)=\left(1-\frac{\text { Mean tumor weight of treated group }}{\text { Mean tumor weight of control group }}\right) \times 100$.

Antitumor activity of $\mathrm{CNG}$ in immunocompromised mice was also tested. $\mathrm{CDF}_{1}$ mice were injected with $5 \mu 1$ of anti-asialo GM1 serum (Wako Chemicals Co., Ltd., Tokyo, Japan) 2 days before, and 4, 10 and 16 days after inoculation of IMC carcinoma cells. These mice were inoculated sc with $1 \times 10^{6}$ IMC carcinoma cells and given $\mathrm{CNG}$ once a week for 4 weeks starting at day 1 after tumor inoculation.

In another experiment, BALB/c nu/nu(-) mice were inoculated sc with $5 \times 10^{5}$ IMC carcinoma cells and were given CNG on the same schedule as above.

\section{Cytotoxic T Lymphocytes and Natural Killer Activities}

Cytotoxic $\mathrm{T}$ lymphocyte (CTL) activity in splenic $\mathrm{T}$ cells and natural killer (NK) activity in unfractionated spleen cells prepared from $\mathrm{CDF}_{1}$ mice were determined against IMC carcinoma cells and YAC-1 cells, respectively. Nylon wool-passed spleen cells were used as $\mathrm{T}$ cells. ${ }^{51} \mathrm{Cr}\left(\mathrm{Na}_{2}{ }^{51} \mathrm{CrO}_{4}\right.$, sp.act. 14.3 GBq/mg, NEZ-030, New England Nuclear, Boston, U.S.A.) labeled IMC carcinoma cells and YAC-1 cells $\left(2 \times 10^{5} \mathrm{cells} / \mathrm{ml}\right)$ were incubated with effector cells at ratios of $100: 1$ for 16 and 4 hours, respectively. After incubation, the supernatants were collected and ${ }^{51} \mathrm{Cr}$ radioactivity was counted in a gamma counter (ARC-300, ALOKA, Tokyo, Japan). After disruption by $1 \%$ SDS the maximum counts in target cells were determined. Triplicate determinations were made. The mean percentage of specific cytotoxicity was calculated as follows: $\%$ cytotoxicity $=\frac{\text { Test count }- \text { Spontaneous count }}{\text { Maximum count }- \text { Spontaneous count }} \times 100$.

Assays for Cytokine Activities

Cytokine activities in the culture supernatants of cells were measured by effects of incorporation of $\left[{ }^{3} \mathrm{H}\right]$ thymidine $\left(\left[{ }^{3} \mathrm{H}\right] \mathrm{TdR}:\left[6-{ }^{3} \mathrm{H}\right]\right.$ thymidine, sp.act. $555 \mathrm{KBq} / \mathrm{mmol}$, NET-355, New England Nuclear, Boston, U.S.A.) into cultured cytokine dependent cell lines.

Monokine production by peritoneal exudate cells (PEC) was determined as follows: PEC were collected by a common method ${ }^{15)}$ from $\mathrm{CNG}$ treated or non-treated tumor bearing mice (washing peritoneal cavity by ip injection of Hanks balanced salt solution (HBSS)) and incubated at $1 \times 10^{5} \mathrm{cells} / \mathrm{ml}$ in RPMI 1640 (Nissui Seiyaku Co. Ltd., Tokyo, Japan) containing $10 \%$ heat inactivated fetal calf serum at $37^{\circ} \mathrm{C}$ in $5 \%$ $\mathrm{CO}_{2}$ for 24 hours. After incubation, the culture supernatants were collected and the supernatants $(100 \mu \mathrm{l} /$ well $)$ and D10.G4.1 cells $\left(1 \times 10^{4}\right.$ cells/well), were cultured with concanavalin A (Con A) $5 \mu \mathrm{g} / \mathrm{ml}$ at $37^{\circ} \mathrm{C}$ in $5 \% \mathrm{CO}_{2}$ for 3 days $^{16)}$. $\left[{ }^{3} \mathrm{H}\right] \mathrm{TdR}$ incorporation into Con A stimulated D10.G4.1. cells, which can grow in the presence of IL-1 ${ }^{17)}$, was used for determination of monokine production by PEC. $\left[{ }^{3} \mathrm{H}\right] \mathrm{TdR}$ was added $(7.4 \mathrm{KBq} /$ well) to cultures 16 hours before cell harvest, and monokine activity was determined by measuring the incorporation of $\left[{ }^{3} \mathrm{H}\right] \mathrm{TdR}$ into the target cells. Triplicate cultures were made for each determination.

Production of lymphokines by splenic T cells was determined as follows: Splenic T cells (nylon wool passed cells) taken from tumor bearing mice given CNG were suspended at $5 \times 10^{6} \mathrm{cells} / \mathrm{ml}$ in RPMI 1640 supplemented $10 \%$ heat inactivated fetal calf serum, $50 \mu \mathrm{M} 2$-mercaptoethanol, nonessential amino acids, $1 \mathrm{mM}$ sodium pyruvate, 50 units $/ \mathrm{ml}$ penicillin and $50 \mu \mathrm{g} / \mathrm{ml}$ streptomycin, and incubated at $37^{\circ} \mathrm{C}$ in $5 \%$ $\mathrm{CO}_{2}$ for 3 days. CTLL-2 and IC-2 cells were used for determination of lymphokine activities ${ }^{18,19)}$. The supernatants $(100 \mu 1 /$ well $)$ and each cell suspension $\left(1 \times 10^{4}\right.$ cells/well) were cultured at $37^{\circ} \mathrm{C}$ in $5 \% \mathrm{CO}_{2}$ for 2 days. The incorporation of $\left[{ }^{3} \mathrm{H}\right] \mathrm{TdR}$ into cells was measured as described above.

Statistical Analysis

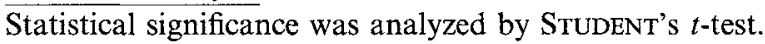




\section{Results}

Antitumor effects of CNG at 0.5 or $5 \mathrm{mg} / \mathrm{kg}$, doses which are effective in enhancing $\mathrm{T}$ cell activities in mice ${ }^{20)}$, were examined against IMC carcinoma in various schedules. As shown in Table 1, although administration of CNG daily at $0.5 \mathrm{mg} / \mathrm{kg}$ and every $3 \mathrm{rd}$ day at $5 \mathrm{mg} / \mathrm{kg}$ had significant antitumor effects of 56 and $40 \%$ inhibition, respectively, weekly administration at 0.5 to $5 \mathrm{mg} / \mathrm{kg}$ inhibited the tumor growth by 47 to $66 \%$. From these results, the antitumor effect of CNG was hereafter examined by weekly administration. As shown in Fig. 1, CNG at 0.05 to $5 \mathrm{mg} / \mathrm{kg}$ exhibited significant antitimor effect but not at $50 \mathrm{mg} / \mathrm{kg}$ did. The tumor growth during CNG therapy is shown in Fig. 2 . CNG at $5 \mathrm{mg} / \mathrm{kg}$ significantly inhibited tumor growth on 21 to 35 days after tumor inoculation.

The antitumor effect of CNG was examined in mice treated with anti-asialo GM1 serum and in athymic mice. As shown in Table 2, in normal mice CNG showed antitumor effects but did not in those immunocompromised mice.

Table 1. Antitumor effect of conagenin (CNG) in different schedules on IMC carcinoma.

\begin{tabular}{|c|c|c|c|}
\hline \multirow{2}{*}{$\begin{array}{c}\mathrm{CNG} \\
(\mathrm{mg} / \mathrm{kg})\end{array}$} & \multicolumn{3}{|c|}{ Therapy on days (days) and tumor weight ( $\mathrm{g} \pm \mathrm{SD})$} \\
\hline & $1 \sim 21$ & $1,4,7 \ldots 19$ & $1,8,15,22$ \\
\hline 0 & $2.87 \pm 1.08 \quad(0)^{\mathrm{a}}$ & $2.87 \pm 1.08 \quad(0)$ & $2.87 \pm 1.08$ \\
\hline 0.5 & $1.27 \pm 0.39 * *(56)$ & $1.82 \pm 1.26 \quad(37)$ & $0.98 \pm 0.28 * * *(66)$ \\
\hline 5 & $1.98 \pm 1.12$ & $1.73 \pm 0.76 *(40)$ & $1.53 \pm 0.83^{*}$ \\
\hline
\end{tabular}

$1 \times 10^{6} \mathrm{IMC}$ carcinoma cells were inoculated sc to $\mathrm{CDF}_{1}$ mice on day $0 . \mathrm{CNG}$ was administered ip on days indicated. Mean tumor weights were determined on day 35 after the inoculation. Each group consisted of 10 mice. ${ }^{a}$ Inhibition rate $(\%) * P<0.05,{ }^{* *} P<0.01$ and *** $P<0.001$ in comparison with control group.

Fig. 1. Antitumor effect of conagenin (CNG) in various doses on IMC carcinoma.

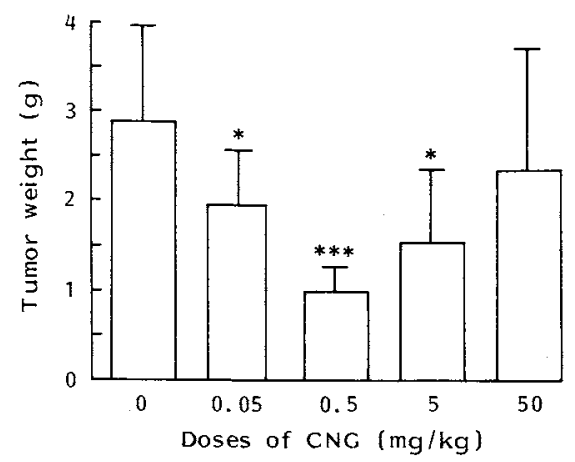

$1 \times 10^{6}$ IMC carcinoma cells were inoculated sc to $\mathrm{CDF}_{1}$ mice on day $0 . \mathrm{CNG}$ was administered ip on days $1,8,15$ and 22. Mean tumor weights were determined on day 35. Each group consisted of 10 mice. ${ }^{*} P<0.05$ and ${ }^{* *} P<0.001$ in comparison with control group.
Fig. 2. Inhibitory effect of conagenin $(\mathrm{CNG})$ on growth of IMC carcinoma.

- Control, a CNG.

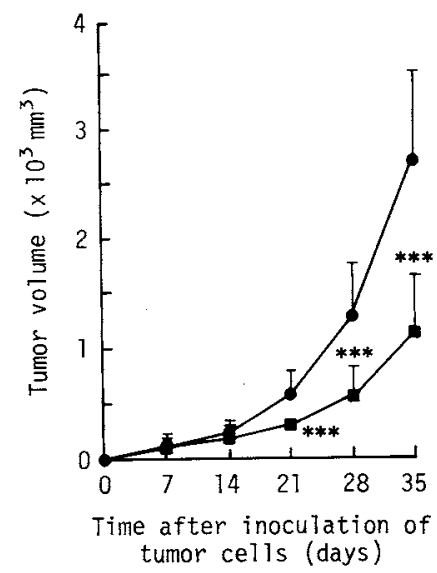

$1 \times 10^{6}$ IMC carcinoma cells were inoculated sc to $\mathrm{CDF}_{1}$ mice on day $0 . \mathrm{CNG}(5 \mathrm{mg} / \mathrm{kg})$ was administered ip on days $1,8,15$ and 22 . Tumor volume was measured on days indicated. Each group consisted of 20 mice. *** $P<0.001$ in comparison with control group. 
Table 2. Reduction of antitumor activity of conagenin (CNG) in immunocompromised mice.

\begin{tabular}{cccc}
\hline & \multicolumn{3}{c}{ Mean tumor weight $(\mathrm{g} \pm \mathrm{SD})$} \\
$\begin{array}{c}\mathrm{CNG} \\
(\mathrm{mg} / \mathrm{kg})\end{array}$ & $\mathrm{CDF}_{1}$ mice & $\begin{array}{c}\mathrm{CDF}_{1} \text { mice } \\
\text { treated with } \\
\alpha \text {-ASGM1 } \\
\text { serum }\end{array}$ & $\begin{array}{c}\text { BALB/c } \\
\mathrm{nu} / \mathrm{nu}(-) \\
\text { mice }\end{array}$ \\
\hline 0 & $2.77 \pm 0.75$ & $5.89 \pm 2.12$ & $3.66 \pm 1.65$ \\
0.5 & $1.03 \pm 0.23^{* *}$ & $6.44 \pm 1.13$ & $2.60 \pm 1.60$ \\
5 & $1.20 \pm 0.76^{*}$ & $6.26 \pm 1.15$ & $3.02 \pm 1.33$ \\
\hline
\end{tabular}

$1 \times 10^{6}$ IMC carcinoma cells were inoculated $\mathrm{sc}$ to $\mathrm{CDF}_{1}$ mice and anti-asialo GMI treated $\mathrm{CDF}_{1}$ mice on day $0.5 \times 10^{5}$ cells were inoculated sc to $\mathrm{BALB} / \mathrm{c}$ $\mathrm{nu} / \mathrm{nu}(-)$ mice. CNG was administered ip on days 1 , 8,15 and 22 after the inoculation of tumor cells. Mean tumor weights were determined on day 35 . Each group consisted of 5 mice. $* P<0.05$ and $* * P<0.01$ in comparison with control group.

In the course of CNG therapy, CTL and NK activities, and cytokine production in tumor bearing mice were monitored every week for 4 weeks. As shown in Fig. 3, CTL and NK activities of antitumor effector cells in tumor bearing mice were reduced in accordance with tumor growth, whereas those effector activities in mice given CNG were maintained at normal levels. These activities were significant in late stages ( 21 to 28 days after tumor inoculation) of tumor growth.

Production of lymphokines by splenic $\mathrm{T}$ cells was determined by $\left[{ }^{3} \mathrm{H}\right] \mathrm{TdR}$ incorporation into cytokine dependent cell lines, CTLL-2 and IC-2 cells.
Fig. 3. Antitumor activities of spleen cells taken from tumor bearing mice given conagenin ( $\mathrm{CNG}$ ).

(A) IMC carcinoma. cells, (B) YAC-1 cells, - control, $\square \mathrm{CNG}$.

(A)

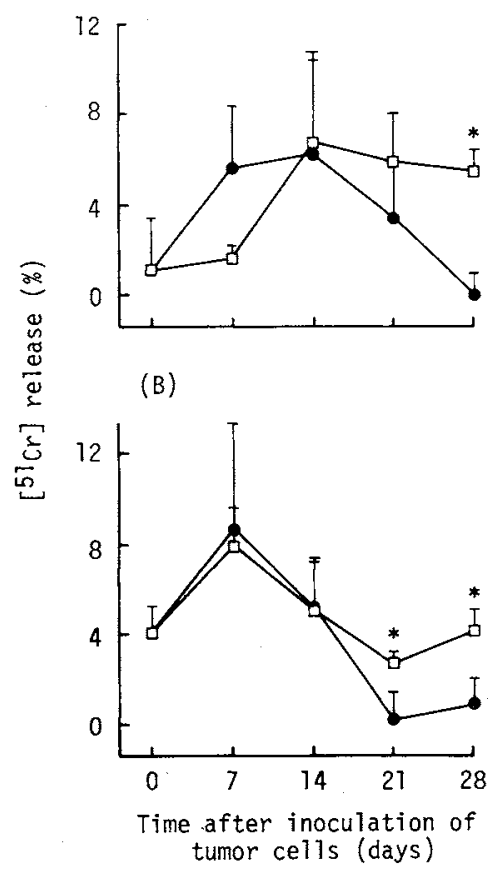

CNG $(5 \mathrm{mg} / \mathrm{kg})$ was administered ip to $\mathrm{IMC}$ carcinoma bearing $\mathrm{CDF}_{1}$ mice on days $1,8,15$ and 22 after the inoculation of tumor cells. Splenic T cells and whole spleen cells were prepared on days indicated and each culture supernatant was provided to assess cytotoxic $T$ lymphocyte and natural killer activities, respectively. Each group consisted of 5 mice. $* P<0.05$ in comparison with control group.

As shown in Fig. 4, the culture supernatants markedly enhanced the incorporation of $\left[{ }^{3} \mathrm{H}\right] \mathrm{TdR}$ into IL-2 dependent CTLL-2 and IL-3 dependent IC-2 cells in 21 and 28 days after tumor inoculation.

On the other hand, monokine production by PEC taken from tumor-bearing mice without CNG increased gradually in accordance with tumor growth whereas it remained in the normal range in mice treated with $\mathrm{CNG}$ at 7,14 and 21 days except at 28 days after tumor inoculation (7 days after the last administration of $\mathrm{CNG}$ ).

\section{Discussion}

The influence of CNG on tumor growth, generation of antitumor effectors and cytokine production in tumor-bearing mice was investigated. Although the administration of CNG daily or on every 3rd day inhibited tumor growth significantly, the most effective schedule in inhibiting tumor growth was weekly administration starting at day 1 or day 8 after tumor inoculation which exhibited a bell-shaped dose response (Fig. 1). Since CNG does not show cytotoxicity to murine (IMC carcinoma, EL-4 thymona, 
Fig. 4. Lymphokine production of splenic T cells taken from tumor bearing mice given conagenin (CNG).

(A) CTLL-2 cells, (B) IC-2 cells, $\bullet$ control, $\square$ CNG.

(A)

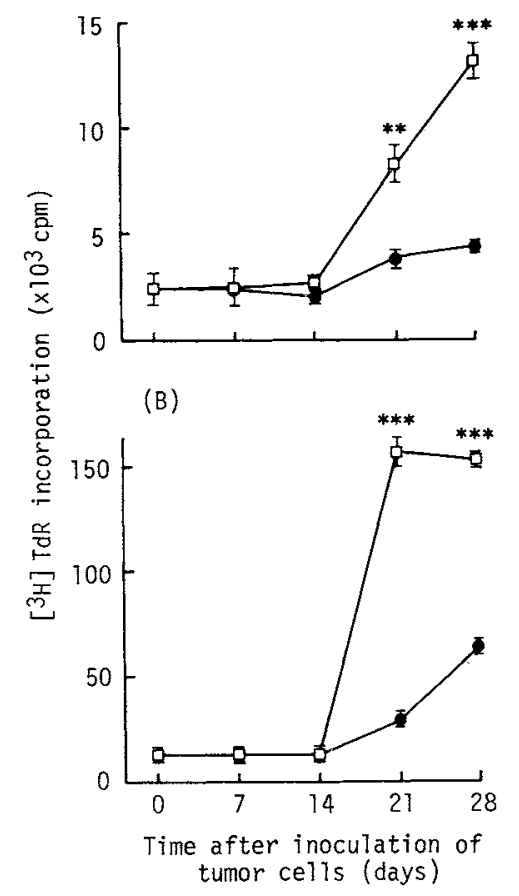

CNG $(5 \mathrm{mg} / \mathrm{kg})$ was administered ip to IMC carcinoma bearing $\mathrm{CDF}_{1}$ mice on days $1,8,15$ and 22 after the inoculation of tumor cells. Splenic T cells were prepared on days indicated and the culture supernatants were provided to measure $\left[{ }^{3} \mathrm{H}\right] \mathrm{TdR}$ incorporation into cytokine dependent cell lines, CTLL-2 and IC-2 cells. Each group consisted of 5 mice. ${ }^{* *} P<0.01$ and ${ }^{* * *} P<0.001$ in comparison with control group.
Fig. 5. Monokine production of adherent peritoneal exudate cells taken from tumor bearing mice given conagenin (CNG).

- Control, a CNG.

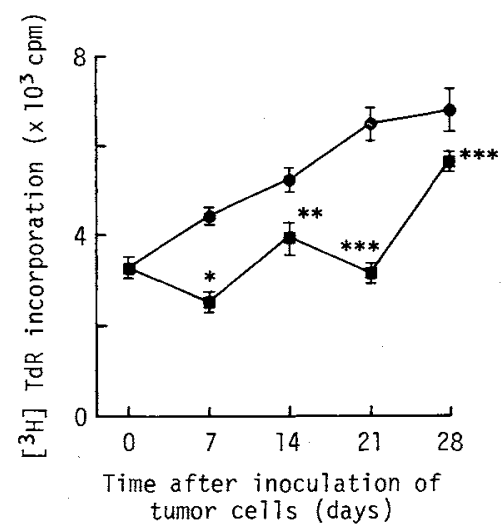

CNG $(5 \mathrm{mg} / \mathrm{kg})$ was administered ip to IMC carcinoma bearing $\mathrm{CDF}_{1}$ mice on days $1,8,15$ and 22 after the inoculation of tumor cells. Adherent peritoneal exudate cells were prepared on days indicated and the culture supernatants were provided to measure $\left[{ }^{3} \mathrm{H}\right] \mathrm{TdR}$ incorporation into cytokine dependent cell line, D10.G4. 1 cells. Each group consisted of 5 mice. $* P<0.05, * * P<0.01$ and ${ }^{* * *} P<0.001$ in comparison with control group.

P815 plasmacytoma) and human tumor cells (SC-6 stomach cancer, LX-1 lung cancer) at more than $100 \mu \mathrm{g} / \mathrm{ml}$ (unpublished data) and the antitumor activity was diminished in immunocompromised mice given anti-asialo GM1 serum and in athymic mice, the antitumor activity of CNG can be considered to be due to host mediated events. Thus, antitumor effectors and cytokine production in tumor-bearing mice given $\mathrm{CNG}$ were monitored.

After inoculation of tumor cells, CTL and NK activities in non-treated mice were concomitantly enhanced for 2 weeks, thereafter, both activities were reduced in accordance with tumor growth, whereas in mice given CNG, CTL maintained high activity. Although NK activity was reduced slightly, it was higher than that of non-treated mice on days 21 and 28 . Though the tumor cells were not sensitive to NK cells, conservation of NK activity at a normal level in mice treated with CNG would be a parameter which shows conservation of host defense mechanisms in the tumor-bearing host. The culture supernatants of $T$ cells taken from tumor-bearing mice given $\mathrm{CNG}$ enhanced the incorporation of $\left[{ }^{3} \mathrm{H}\right] \mathrm{TdR}$ into CTLL-2 cells and IC-2 cells in late stage of tumor growth when the activity of antitumor effector cells such as CTL and NK cells appeared to be higher than those of non-treated mice. CTLL-2 and IC-2 cells are used for assessment of lymphokine activities such as $\mathrm{IL}-2, \mathrm{IL}-4^{18,21)}$ and $\mathrm{IL}-3, \mathrm{GM}-\mathrm{CSF}^{22)}$, respectively. These results suggest that CNG stimulates $\mathrm{T}$ cells to produce lymphokines which act on generation of antitumor effector cells derived from T lineage cells such as CTL and NK cells in tumor bearing mice.

In tumor-bearing mice, monokine production by PEC was gradually augmented in accordance with the tumor growth whereas CNG treatment inhibited this augmentation and kept it in a normal range. It is known that inflammatory mediators, IL-1, TGF- $\beta$, TNF- $\alpha$ etc., are produced by activated macrophages, and IL-1 and cachectin/TNF- $\alpha$ may be mediators of cachexia ${ }^{23,24)}$. Thus, it may be possible that CNG 
prevents chronic inflammatory responses caused by macrophages, although CNG does not modulate monokine production by macrophages in vitro.

In this study, it is shown that a low molecular weight immunomodulator CNG which stimulates activated $T$ cells inhibits the growth of a syngeneic solid tumor in mice. CNG therapy, weekly for 4 times starting 1 day after tumor inoculation, enhanced lymphokine production and generation of antitumor effector cells on days 21 and 28 in tumor-bearing mice. It prevented increase of monokine production by macrophages in accordance with tumor growth. Elsewhere, it will be reported that CNG stimulated T cells in bone marrow to produce megakaryocytes and improves the reduced platelet counts in peripheral blood of mice given cyclophosphamide ${ }^{25)}$. A low molecular weight immunomodulator like CNG which stimulates activated $\mathrm{T}$ cells may be useful for cancer treatment.

\section{Acknowledgment}

This work was supported in part by Grant-in-Aid for Cancer Research from the Ministry of Education, Science and Culture, Japan.

\section{References}

1) Ishizuka, M.; J. Sato, Y. Sugiyama, T. Takeuchi \& H. Umezawa: Mitogenic effect of bestatin of lymphocytes. J. Antibiotics 33: 653 662, 1980

2) Ishizuka, M.; S. Ishizeki, T. Masuda, A. Momose, T. Aoyagi, T. Takeuchi \& H. UmeZawa: Studies on effects of forphenicinol on immune responses. J. Antibiotics 35: 1042 1048, 1982

3) MatTer, A.: The effect of muramyldipeptide (MDP) in cell-mediated immunity. Cancer Immunol. Immunother. 6: $201 \sim 210,1979$

4) Ishizuka, M.; T. Masuda, N. Kanbayashi, S. Fukasawa, T. Takeuchi, T. Aoyagi \& H. Umezawa: Effect of bestatin on mouse immune system and experimental murine tumors. J. Antibiotics 33: 642 652, 1980

5) Abe, F.; K. Shibuya, M. Uchida, K. Takahashi, H. Horinishi, A. Matsuda, T. Takeuchi \& H. Umezawa: Effect of bestatin on syngeneic tumors in mice. Gann 75: 89 94, 1984

6) Okura, A.; Y. SaWaZaki, K. Natto, M. Ishizuka, T. Takeuchi \& H. UmeZaWa: Antitumor effect of forphenicinol, a low molecular weight immunomodifier, in combination with surgery on Meth A fibrosarcoma, lewis lung carcinoma, and adenocarcinoma 755. J. Antibiotics 39: 564 568, 1986

7) Okura, A.; K. Naito, H. IzzuKa, M. IshizuKa, T. Takeuchi \& H. Umezawa: Effect of forphenicinol, a low molecular weight immunomodifier, on the growth of and the immune responses to murine lymphoma EL-4. J. Biol. Res. Mod. 6: 35 43, 1987

8) Suga, T.; T. Shio, Y. Y. Maeda \& G. Chihara: Antitumor activity of lentinan in murine syngeneic and autochrhonous hosts and its suppressive effect on 2-methylcholanthrene-induced carcinogenesis. Cancer Res. 44: $5132 \sim 5137,1984$

9) Fruehauf, J. P.; G. D. Bonnard \& R. B. Herbeman: The effect of lentinan on production of interleukin-1 by human monocytes. Immunopharmacology 5: 65 74, 1982

10) Zakany, J.: G. Chimara \& J. FaChet: Effect of lentinan on tumor growth in murine allogeneic and syngeneic hosts: Int. J. Cancer 25: $371 \sim 376,1980$

11) SugawARA, I.; K. C. LEE \& M. WONG: Schizophyllan (SPG)-treated macrophages and anti-tumor activities against syngeneic and allogeneic tumor cells. I. Characteristics of SPG-treated macrophages. Cancer Immuno. Immunother. 16: $137 \sim 144,1980$

12) Komatsu, N.; S. OKubo, S. Kikumoto, K. Kimura, G. Saito \& S. SaKai: Host-mediated antitumor action of schizophyllan, a glucan produced by Schizophyllum commune. Gann 60: 137 144, 1969

13) TsuKagoshi, S. \& F. OHASHI: Protein-bound polysaccharide preparation, PS-K, effective against mouse sarcoma-180 and rat ascites hepatoma AH-13 by oral use. Gann 65: 557 558, 1974

14) Yamashita, T.; M. IIjIma, H. Nakamura, K. Isshiki, H. Naganawa, S. Hattori, M. Hamada, M. Ishizuka, T. TAKeuchi \& Y. IItAKa: Conagenin, a low molecular weight immunomodulator produced by Streptomyces roseosporus. J. Antibiotics 44: $557 \sim 559,1991$

15) Shibuya, K.; E. Hayashi, F. Abe, K. Takahashi, H. Horinishi, M. Ishizuka, T. Takeuchi \& H. Umezawa: Enhancement of interleukin 1 and interleukin 2 releases by ubenimex. J. Antibiotics 40: 363 369, 1987

16) KAYE, J. \& C. A. JANEWAY, Jr.: Induction of receptors for interleukin 2 requires T cell Ag: Ia receptor crosslinking and interleukin 1. Lymphokine Res. 3: 175 182, 1984

17) Kaye, J.; S. Gillis, S. B. Mizel, E. M. Shevach, T. R. Malek, C. A. Dinarello, L. B. Lachman \& C. A. JANEWAY, Jr.: Growth of a cloned helper $\mathrm{T}$ cell line induced by a monoclonal antibody specific for the antigen 
receptor: Interleukin 1 is required for the expression of receptors for interleukin 2. J. Immunol. 133: 1339 1345, 1984

18) GILlis, S.; M. M. FeRM, W. OU \& K. A. SMITH: T cell growth factor: parameter of production and a quantitative microassay for activity. J. Immunol. 120: 2027 2032, 1978

19) Koyasu, S.; H. Nakauchi, K. Kitamura, S. Yonehara, K. Okumura, T. Tada \& I. Yahara: Production of interleukin 3 and $\gamma$-interferon by an antigen-specific mouse suppressor T cell clone. J. Immunol. 134: $3130 \sim 3136$, 1985

20) Kawatsu, M.; T. Yamashita, M. Osono, M. Ishizuka \& T. Takeuchi: T cell activation by conagenin in mice. J. Antibiotics 46: 1687 1691, 1993

21) Hu-Li, J.; J. Ohara, C. Watson, W. Tsang \& W. E. Paul: Derivation of a T cell line that is highly responsive to IL-4 and IL-2 (CT. 4R) and of an IL-2 hyporesponsive mutant of that line (CT. 4S). J. Immunol. 142: 800 807, 1989

22) Prestidge, R. L.; J. D. Watson, D. L. Urdal, D. Mochizuki, P. Conlon \& S. Gillis: Biochemical comparison of murine colony stimulating factors secreted by a $\mathrm{T}$ cell lymphoma and a myelomonocytic leukemia. J. Immunol. 133: $293 \sim 298,1984$

23) Langstein, H. N. \& J. A. Norton: Mechanisms of cancer cachexia. Hematology/Oncology Clinics of North America 5: $103 \sim 123,1991$

24) Langstein, H. N.; G. M. Doherty, D. L. Fraker, C. M. Buresh \& J. A. Norton: The role of $\gamma$-interferon and tumor necrosis factor $\alpha$ in an experimental rat model of cancer cachexia. Cancer Res. 51: 2302 2306, 1991

25) IshizuKa, M.; T. Yamashita, M. Kawatsu, T. Takeuchi, T. Katsumi \& T. Shiraishi: Conagenin, a low molecular weight immunomodulator produced by Streptomyces roseosporus, on murine tumors and platelet production. Abstracts of 18th International Congress of Chemotherapy, No. 1125, P. 310, Stockholm, 1993 